\title{
Home-based music therapy - a systematic overview of settings and conditions for an innovative service in healthcare
}

\author{
Wolfgang Schmid ${ }^{1}$, Thomas Ostermann ${ }^{2^{*}}$
}

\begin{abstract}
Background: Almost every Western healthcare system is changing to make their services more centered around out-patient care. In particular, long-term or geriatric patients who have been discharged from the hospital often require home-based care and therapy. Therefore, several programs have been developed to continue the therapeutic process and manage the special needs of patients after discharge from hospital. Music therapy has also moved into this field of healthcare service by providing home-based music therapy (HBMT) programs. This article reviews and summarizes the settings and conditions of HBMT for the first time.

Methods: The following databases were used to find articles on home-based music therapy: AMED, CAIRSS, EMBASE, MEDLINE, PsychINFO, and PSYNDEX. The search terms were "home-based music therapy" and "mobile music therapy". Included articles were analyzed with respect to participants as well as conditions and settings of HBMT. Furthermore, the date of publication, main outcomes, and the design and quality of the studies were investigated.

Results: A total of 20 international publications, 11 clinical studies and nine reports from practice, mainly from the United States $(n=8)$, were finally included in the qualitative synthesis. Six studies had a randomized controlled design and included a total of 507 patients. The vast majority of clients of HBMT are elderly patients living at home and people who need hospice and palliative care. Although settings were heterogeneous, music listening programs played a predominant role with the aim to reduce symptoms like depression and pain, or to improve quality of life and the relationship between patients and caregivers as primary endpoints.

Conclusions: We were able to show that HBMT is an innovative service for future healthcare delivery. It fits with the changing healthcare system and its conditions but also meets the therapeutic needs of the increasing number of elderly and severely impaired people. Apart from music therapists, patients and their families HBMT is also interesting as a blueprint for home based care for other groups of caregivers.
\end{abstract}

\section{Background}

The use of music as a therapeutic option to support health dates back to ancient times. According to Bailey [1] some of the earliest notable mentions in Western history are found in the writings of ancient Greek philosophers Aristotle and Plato. In contemporary history, Michigan State University offered the first music therapy degree program worldwide in 1944. From that point, music therapy has established itself as a growing health profession for

\footnotetext{
* Correspondence: thomaso@uni-wh.de

${ }^{2}$ Center of Integrative Medicine \& Chair of Medical Theory, Integrative and Anthroposophical Medicine, Witten/Herdecke University, Herdecke, Germany Full list of author information is available at the end of the article
}

inpatients treatment of psychiatric diseases like schizophrenia or schizophrenia-like illnesses [2], psychosis [3], neurological diseases like multiple sclerosis [4], dementia [5], or for the treatment of patients with chronic pain [6,7].

Due to changes over the last few decades in almost every Western healthcare system towards more outpatientcentred healthcare programs, music therapy also moved into the field of primary care. The first MEDLINE-listed report on music therapy in a day care centre was already published by Pierce et al. [8] in 1964. Since then, music therapy as a discipline has developed its methods and working fields in manifold ways and has also proven to be effective in the field of ambulatory work. For the treatment 
of chronic diseases, in particular study results for the treatment of tinnitus [9], cardiac rehabilitation patients [10,11], or oncological patients [12], reveal the effectiveness of music therapy also in primary care settings.

Under these circumstances music therapy concepts are of fundamental interest for the continuity of care between in- and outpatient treatment. In particular, severely impaired or geriatric patients discharged from hospital risk losing therapeutic continuity because they are often not able to attend day care centres where music therapy is provided. Therefore, two major directions have been established within the field of music therapy. On the one hand, community music therapy programs focusing on the social and cultural relations of the client and establishing music therapy within his or her social context [13]; on the other hand, music therapy initiatives providing homebased music therapy (HBMT) in manifold projects are of increasing importance [14]. Such HBMT-approaches focus on the perspective of a patient's condition after clinic or rehabilitation and the continuity of the therapeutic process. Specifically for patients after a traumatic brain injury, chronic diseases as well as in palliative and dementia care, a long term treatment concept should include not only functional therapies but also mind-body interventions like music therapy in order to meet the emotional, social, and communicative needs of a patient and to accompany him or her in their coping process [15].

For the first time, this systematic overview focuses on settings and conditions of home-based music therapy programs. The main questions were whether and if so how HBMT can be part of an innovative and effective service for people who have to be treated at home.

\section{Methods}

The following electronic databases were used to find articles on home-based music therapy: AMED, CAIRSS, EMBASE, MEDLINE, PsychINFO, and PSYNDEX. Databases were searched from their inception until 2010. The search terms were "home-based music therapy" and "mobile music therapy". In addition, an internet search was performed using Google Scholar. All articles found this way were fully read and their reference lists were checked for further relevant publications. To address a wide range of HBMT, there were no limitations in the initial search in terms of language, year, status, and form of publication. One of the inclusion criteria for all publications was that the music therapy services had to take place in the home of the clients. Therefore, all publications on other out-patient music therapy services were excluded. The complete search strategy together with the number of excluded studies is given in Figure 1.

If a study was found to be eligible, its methodological quality was assessed by two independent reviewers and recorded on a pre-determined checklist together with the basic trial data regarding participants, interventions, settings, outcomes, and study designs (PICOS) [16]. This specifically included quality and duration of MT intervention and appraisal of MT-specific outcomes. Disagreements in data extraction were resolved by consensus. Although blinding of patients in music therapy is not applicable and thus the use of the JADAD score [17] is problematic, the reviewers tried to grade the methodological quality of the studies by the following checklist (interrater assessment): adequate description of the study design (retrospective, prospective, multicentre study), subject assembly process (randomization, matched pairs, etc.), comparability of groups, description of drop outs, allocation concealment, description of the intervention, description of statistical analysis, external validity (representative patients, relevant therapeutic concepts, generalization of results).

As the anticipated outcome was assumed to be a mixture of approaches, settings, legal aspects and outcomes relating to the perspectives of the patients, caregivers, and relatives and also due to the expectation of a quite heterogeneous data with respect to study design and used outcome measures, the authors decided against carrying out a meta-analysis of the results and decided to present the findings in a qualitative data synthesis.

\section{Results}

In total, the search identified 93 records after removing duplications. Of those, 61 did not sufficiently cover the field of home-based music therapy or were related to other therapeutic interventions. Thirty-two publications were found to be eligible for full text screening. However, another 15 articles had to be excluded due to reasons of setting while three additional articles, which had not been found by the database search, were retrieved from contacted authors (See Figure 1).

Finally, 20 international publications from the United States $(\mathrm{n}=8)$, Germany $(\mathrm{n}=4)$, Australia $(\mathrm{n}=5)$, Austria $(\mathrm{n}=1)$, Japan $(\mathrm{n}=1)$, and New Zealand $(\mathrm{n}=1)$ were included in the qualitative synthesis (see Tables 1 and 2 for details). From those 20 publications, 11 are clinical studies and nine are reports from practice including field or project reports with single case studies or special music therapy programs for HBMT as well as legal and administrative aspects of HBMT. The 11 studies investigate the effectiveness of HBMT on certain symptoms, mainly on depression, anxiety, distress, and pain [18-21], but also on dyspnea [22], the length and quality of life [23], or the promotion of social skills from autistic children $[24,25]$. Four studies concentrate on the question of how HBMT could meet not only the needs of the patients, but also the needs of caregivers, spouses, and families [26-29]. One study investigates new strategies to improve therapy outcomes of depression treatment due 


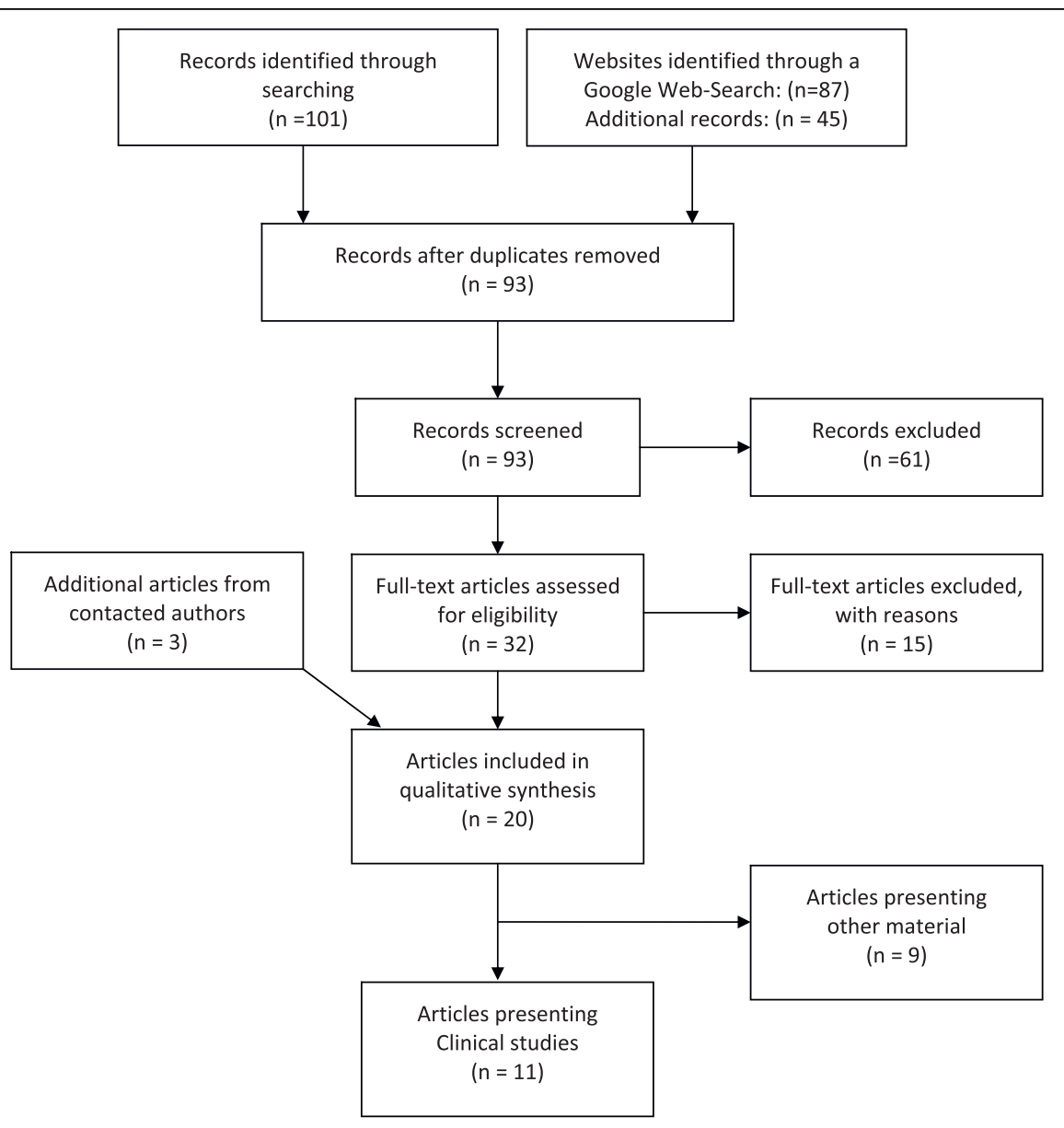

Figure 1 Flowchart of the literature review process.

to the fact that only less than half of the diagnosed patients with depression seem to respond to psychosocial or antidepressant treatment [18].

Although cost effectiveness of HBMT is an intrinsic motivation for most of the studies, it is mentioned directly by only one author [19].

To establish a level of quality and understanding of the search and the results of this review, the authors decided to analyze only the 11 clinical studies. With respect to music therapy as a young discipline in health services research and the pioneering character of homebased music therapy work in practice, the nine reports and technical papers are listed in Table 2.

\section{Study design}

Of the 20 publications, 11 describe outcome studies. Although all studies can be considered small with respect to the number of patients involved, the methodological quality of the studies can be regarded to be quite high. All studies clearly name the outcome parameters, with the majority having a reduction of symptoms like depression or pain or an improvement of quality of life and the relationship between patients and caregivers as primary endpoints. Six studies have a randomized controlled design. The randomized studies include a total of 507 patients, varying form $n=14$ to 203 with a mean of 85 participants. A closer analysis of the studies with a modified JADAD score [17] resulted in scores between 1 and 2 due to the impossibility of blinding in music therapy.

\section{Settings and Interventions}

The studies on HBMT show a variety of music therapy interventions and techniques, including active as well as receptive music therapy approaches, and, in one study, Individualized Music-focused Audio Therapies (IMATs) [18]. Although both active and receptive music therapy can be found in home-based settings, music listening programs play an important role [21,22,27]. In only a few studies, the therapist offered both active and receptive music therapy $[24,25]$.

The musical repertoire offered to the patients contains classical music, new age music or easy listening music 
Table 1 Studies in HBMT

\begin{tabular}{|c|c|c|c|c|c|c|c|c|}
\hline Authors & Year & Country & $\begin{array}{l}\text { Participants/ } \\
\text { Conditions }\end{array}$ & Purpose of the study & Intervention/HBMT Technique & Comparison & Outcomes & Study design \\
\hline $\begin{array}{l}\text { Hanser, SB \& } \\
\text { Thomson, LW }\end{array}$ & 1994 & USA & $\begin{array}{l}30 \text { depressed home- } \\
\text { bound adults ranged } \\
\text { in age from } 61 \text { to } 86\end{array}$ & $\begin{array}{l}\text { To examine a music- } \\
\text { facilitated } \\
\text { psychoeducational strategy } \\
\text { as a cost-effective and } \\
\text { accessible intervention }\end{array}$ & $\begin{array}{l}8 \text { week program of receptive MT } \\
\text { including } 8 \mathrm{MT} \text {-techniques } \\
\text { combined with mind/body } \\
\text { interventions }\end{array}$ & $\begin{array}{l}\text { Three groups with } 10 \\
\text { patients each: (1) HBMT, } \\
\text { (2) phone administered, } \\
\text { and (3) control }\end{array}$ & $\begin{array}{l}\text { Both HBMT and self- } \\
\text { administered MT significantly } \\
\text { increased in tests of } \\
\text { depression, distress, self- } \\
\text { esteem, and mood and } \\
\text { remained stable after } 9 \\
\text { month follow up }\end{array}$ & $\begin{array}{l}\text { 3-armed RCT } \\
\text { with 9-month } \\
\text { follow-up }\end{array}$ \\
\hline Shiraishi, IM & 1997 & USA & $\begin{array}{l}14 \text { multi-risk mothers } \\
\text { ranged in age from } \\
21 \text { to } 41 \text { years }\end{array}$ & $\begin{array}{l}\text { To explore the prevalence } \\
\text { of anxiety and depression } \\
\text { and the effectiveness of MT } \\
\text { on these symptoms }\end{array}$ & 8 week program of receptive MT & $\begin{array}{l}\text { Three groups: (1) control } \\
(n=4),(2) \text { phone } \\
\text { administered }(n=5) \text { and } \\
\text { (3) HBMT }(n=5)\end{array}$ & $\begin{array}{l}\text { Both HBMT and phone } \\
\text { administered MT decreased } \\
\text { depression and increased } \\
\text { self-esteem levels. HBMT had } \\
\text { subjective better gains than } \\
\text { phone administered mothers }\end{array}$ & 3-armed RCT \\
\hline McBride, S & 1999 & USA & $\begin{array}{l}24 \text { patients with } \\
\text { chronic obstructive } \\
\text { pulmonary disease } \\
\text { (COPD) (mean age: } 69 \\
\pm 5,7 \text { years) }\end{array}$ & $\begin{array}{l}\text { To examine the feasibility } \\
\text { of using music as an } \\
\text { intervention for dyspnea } \\
\text { and anxiety }\end{array}$ & $\begin{array}{l}\text { Receptive instrumental MT } \\
\text { (classical, new age, easy listening) } \\
\text { on an individual schedule }\end{array}$ & No comparison & $\begin{array}{l}\text { Using preferred music as an } \\
\text { intervention led to a decline } \\
\text { of dyspnea and anxiety }\end{array}$ & $\begin{array}{l}\text { Single armed } \\
\text { observational } \\
\text { study with } \\
\text { repeated } \\
\text { measures }\end{array}$ \\
\hline Hilliard, RE & 2003 & USA & $\begin{array}{l}80 \text { adults diagnosed } \\
\text { with terminal cancer } \\
\text { (mean age: } 66 \text { years } \\
\text { (MT group) and } 65 \\
\text { (control group) }\end{array}$ & $\begin{array}{l}\text { To evaluate the effects of } \\
\text { MT on quality of life and } \\
\text { length of life in care }\end{array}$ & $\begin{array}{l}\text { Individualized music therapy with } \\
\text { a variety of interventions, e.g. } \\
\text { singing, listening or instrument } \\
\text { playing }\end{array}$ & $\begin{array}{l}\text { Two groups: (1) Routine } \\
\text { hospice services and MT } \\
\text { versus (2) routine hospice } \\
\text { services only }\end{array}$ & $\begin{array}{l}\text { Results clearly support music } \\
\text { therapy in hospice and } \\
\text { palliative care for improving } \\
\text { quality of life of people } \\
\text { diagnosed with terminal } \\
\text { cancer }\end{array}$ & $\begin{array}{l}\text { Randomized } \\
\text { experimental } \\
\text { control-group } \\
\text { design }\end{array}$ \\
\hline Pasiali, V & 2004 & USA & $\begin{array}{l}3 \text { children ( } 7,8 \text { and } 9 \\
\text { years old) with autism } \\
\text { (diagnosis ranging } \\
\text { from high functioning } \\
\text { to mildly impaired) }\end{array}$ & $\begin{array}{l}\text { To investigate the effect of } \\
\text { presciptive songs on } \\
\text { promoting social skills } \\
\text { aquisition by autistic } \\
\text { children }\end{array}$ & Prescriptive therapeutic songs & No comparison & $\begin{array}{l}\text { Results are not conclusive, } \\
\text { but there are some hints that } \\
\text { prescriptive songs are a } \\
\text { viable intervention for } \\
\text { children with autism }\end{array}$ & $\begin{array}{l}\text { Three case } \\
\text { studies with } \\
\text { ABAB reversal } \\
\text { design }\end{array}$ \\
\hline Siedlecki, SL & 2005 & USA & $\begin{array}{l}60 \text { patients aged from } \\
21 \text { to } 65 \text { with chronic } \\
\text { non-malignant pain } \\
\text { (CNMP) }\end{array}$ & $\begin{array}{l}\text { To examine the effect of } \\
\text { two music-listening } \\
\text { interventions on measures } \\
\text { of power, pain, depression, } \\
\text { and disability in individuals } \\
\text { with chronic non-malignant } \\
\text { pain }\end{array}$ & $\begin{array}{l}\text { Two music-listening interventions: } \\
\text { a standard music (SM) } \\
\text { intervention and a patterned } \\
\text { music therapy (PM) intervention } \\
\text { with pleasant familiar } \\
\text { instrumental or vocal music or } \\
\text { the sounds of nature }\end{array}$ & $\begin{array}{l}\text { Three groups: (1) } \\
\text { standard care without } \\
\text { MT, (2) standard music } \\
\text { interventions, (3) a } \\
\text { patterned music therapy }\end{array}$ & $\begin{array}{l}\text { Both music-listening } \\
\text { interventions were equally } \\
\text { effective for increasing } \\
\text { power, and decreasing pain, } \\
\text { depressive symptoms, and } \\
\text { disability associated with } \\
\text { CNMP. Patients were taught } \\
\text { to use music at home to } \\
\text { moderate these symptoms }\end{array}$ & 3 armed RCT \\
\hline Muthesius, D & 2005 & Germany & $\begin{array}{l}40 \text { patients with } \\
\text { dementia }\end{array}$ & $\begin{array}{l}\text { To explore the effectiveness } \\
\text { of HBMT and the linked } \\
\text { support for the caring } \\
\text { situation }\end{array}$ & $\begin{array}{l}\text { Singing songs and playing } \\
\text { familiar music }\end{array}$ & No comparison & $\begin{array}{l}\text { Similar effects to in-house } \\
\text { treatment like emotional } \\
\text { support or orientation. More } \\
\text { and detailed biographical } \\
\text { details from patients, their } \\
\text { musical resources support } \\
\text { carers and relatives to get } \\
\text { positive impressions of the } \\
\text { patients }\end{array}$ & $\begin{array}{l}\text { Observational } \\
\text { study with } \\
\text { nested in } \\
\text { single case } \\
\text { vignettes }\end{array}$ \\
\hline
\end{tabular}


Table 1 Studies in HBMT (Continued)

\begin{tabular}{|c|c|c|c|c|c|c|c|c|}
\hline Chiang, JYK & 2008 & $\begin{array}{l}\text { New } \\
\text { Zealand }\end{array}$ & $\begin{array}{l}4 \text { carers (three } \\
\text { mothers and one } \\
\text { speech-langu age } \\
\text { therapist) of children } \\
\text { with special needs }\end{array}$ & $\begin{array}{l}\text { To investigate how } \\
\text { carergivers and other } \\
\text { professionals perceive the } \\
\text { music therapy process over } \\
\text { time }\end{array}$ & $\begin{array}{l}\text { Instrument playing, movement } \\
\text { and listening to music, and } \\
\text { singing of songs }\end{array}$ & No comparison & $\begin{array}{l}\text { From the perspective of } \\
\text { caregivers, music therapy } \\
\text { allows them to collaborate } \\
\text { with the music therapist. MT } \\
\text { contributes to the } \\
\text { development of reflective } \\
\text { skills for delivering effective } \\
\text { professional practice }\end{array}$ & $\begin{array}{l}\text { Explorational } \\
\text { qualitative } \\
\text { study design } \\
\text { with semi- } \\
\text { structured } \\
\text { interviews }\end{array}$ \\
\hline Baker, F et al. & $\begin{array}{l}\text { On- } \\
\text { going }\end{array}$ & Australia & $\begin{array}{l}120 \text { couples where } \\
\text { one partner has a } \\
\text { probable diagnosis of } \\
\text { dementia }\end{array}$ & $\begin{array}{l}\text { To advance the } \\
\text { understanding of MT- } \\
\text { techniques to enhance } \\
\text { spousal relationship and } \\
\text { reduce functional and } \\
\text { emotional strain on the } \\
\text { spousal caregiver }\end{array}$ & $\begin{array}{l}\text { Singing familiar songs, movement } \\
\text { to music, listening to music } \\
\text { control: recreational reading } \\
\text { intervention }\end{array}$ & $\begin{array}{l}\text { Two groups: (1) active } \\
\text { music intervention and } \\
\text { (2) control group with } \\
\text { recreational reading }\end{array}$ & Ongoing study & 2 armed RCT \\
\hline $\begin{array}{l}\text { Thomas, A, } \\
\text { et al. }\end{array}$ & 2009 & Australia & $\begin{array}{l}191 \text { clients of the } \\
\text { Eastern Palliative Care } \\
\text { (EPC) from } 2007 \text { to } \\
2008\end{array}$ & $\begin{array}{l}\text { To evaluate the } \\
\text { effectiveness of single MT } \\
\text { in community based } \\
\text { palliative care. Perspectives } \\
\text { of clients, carers and } \\
\text { therapists are included }\end{array}$ & $\begin{array}{l}\text { Live or recorded music provided } \\
\text { by Registered Music Therapists at } \\
\text { the EPC who are specifically } \\
\text { trained to support people in their } \\
\text { own home with music therapy } \\
\text { sessions }\end{array}$ & No comparison & $\begin{array}{l}\text { Music therapy supports } \\
\text { clients with a life-threatening } \\
\text { illness to maintain and/or } \\
\text { improve their quality of life } \\
\text { and also supports family } \\
\text { members in their role as } \\
\text { caregivers. }\end{array}$ & $\begin{array}{l}\text { Observational } \\
\text { study with } \\
\text { nested in } \\
\text { qualitative } \\
\text { study }\end{array}$ \\
\hline Brandes, V & 2010 & Austria & $\begin{array}{l}203 \text { patients with } \\
\text { depression and/or } \\
\text { burnout and an } \\
\text { average age of } 49,6 \\
+13,1 \text { years }\end{array}$ & $\begin{array}{l}\text { To investigate new } \\
\text { strategies to improve } \\
\text { therapy outcomes in } \\
\text { psychosocial and } \\
\text { antidepressant treatment }\end{array}$ & $\begin{array}{l}\text { Individualized short-term } \\
\text { receptive music therapy. MT was } \\
\text { administered as single therapy or } \\
\text { add-on therapy to } \\
\text { antidepressants and/or } \\
\text { psychotherapy }\end{array}$ & $\begin{array}{l}\text { Four groups: (1) MT with } \\
\text { specific newly composed } \\
\text { music, (2) MT with } \\
\text { specially arranged } \\
\text { classical music, (3) a } \\
\text { placebo group receiving } \\
\text { nature sounds, and (4) a } \\
\text { waiting-list control group. }\end{array}$ & $\begin{array}{l}\text { Individualized short-term } \\
\text { music therapy is beneficial as } \\
\text { alternative or complementary } \\
\text { depression treatment }\end{array}$ & 4 armed RCT \\
\hline
\end{tabular}


Table 2 Reports from HBMT-Practice

\begin{tabular}{|c|c|c|c|c|c|c|c|}
\hline Author & Year & Country & $\begin{array}{l}\text { Type of } \\
\text { publication }\end{array}$ & Participants/Conditions & Purpose of the publication & $\begin{array}{l}\text { Intervention/HBMT- } \\
\text { Technique }\end{array}$ & Outcomes \\
\hline Oliver, S & 1989 & USA & $\begin{array}{l}\text { Journal } \\
\text { article }\end{array}$ & $\begin{array}{l}\text { Developmentally disabled } \\
\text { adults and children, acute } \\
\text { and chronic psychiatric } \\
\text { adults }\end{array}$ & $\begin{array}{l}\text { To report on music therapy services including } \\
\text { HBMT }\end{array}$ & $\begin{array}{l}\text { Group and single } \\
\text { music therapy }\end{array}$ & $\begin{array}{l}\text { Information related to conceptualizing, } \\
\text { initiating, and maintaining a private } \\
\text { practice in the music therapy field }\end{array}$ \\
\hline Hanser, SB. & 1990 & USA & $\begin{array}{l}\text { Journal } \\
\text { article }\end{array}$ & $\begin{array}{l}4 \text { depressed older adults in } \\
\text { age from } 64 \text { to } 75 \text { years }\end{array}$ & $\begin{array}{l}\text { To document and evaluate the implementation of } \\
\text { a home based MT-technique }\end{array}$ & $\begin{array}{l}\text { Eight music listening } \\
\text { programs in } \\
\text { conjunction with } \\
\text { known relaxation } \\
\text { methods }\end{array}$ & $\begin{array}{l}\text { Four case studies describe successful } \\
\text { application of MT to older adults with } \\
\text { depression and/or anxiety }\end{array}$ \\
\hline $\begin{array}{l}\text { Horne- } \\
\text { Thompson, } \\
\text { A }\end{array}$ & 2003 & Australia & $\begin{array}{l}\text { Journal } \\
\text { article }\end{array}$ & Patients in palliative care & $\begin{array}{l}\text { To compare the role of music therapy within a } \\
\text { palliative care facility as opposed to a home }\end{array}$ & $\begin{array}{l}\text { No detailled } \\
\text { information }\end{array}$ & $\begin{array}{l}\text { The role of HBMT as opposed to the } \\
\text { hospital varies markedly. The necessity to } \\
\text { consider new ways to address the needs of } \\
\text { patients and their families is emphasized }\end{array}$ \\
\hline Weber, S & 2003 & Germany & $\begin{array}{l}\text { Bachelor } \\
\text { thesis }\end{array}$ & $\begin{array}{l}\text { Children from } \\
\text { underprivilegedfamilies }\end{array}$ & $\begin{array}{l}\text { Review of legal and administrative aspects of HBMT } \\
\text { and a single case study }\end{array}$ & $\begin{array}{l}\text { Half year family } \\
\text { intervention including } \\
\text { active single and } \\
\text { group music therapy } \\
\text { sessions }\end{array}$ & $\begin{array}{l}\text { HBMT as a new form of socio-paedagogical } \\
\text { interventions is successful and cost } \\
\text { effective with respect to improvements in } \\
\text { family dynamics }\end{array}$ \\
\hline $\begin{array}{l}\text { Chapman, } \\
\text { A. }\end{array}$ & 2004 & Australia & $\begin{array}{l}\text { Conference } \\
\text { talk }\end{array}$ & $\begin{array}{l}\text { Autistic children, a young } \\
\text { adult with a physical and } \\
\text { intellectual disability and an } \\
\text { older woman with dementia }\end{array}$ & $\begin{array}{l}\text { To present practical experiences and considerations } \\
\text { on HBMT }\end{array}$ & $\begin{array}{l}\text { Playing instruments, } \\
\text { singing songs, } \\
\text { vocalizing }\end{array}$ & $\begin{array}{l}\text { Working in the home of a client and his/ } \\
\text { her family allows current circumstances to } \\
\text { be incorporated and enhance this intimacy }\end{array}$ \\
\hline $\begin{array}{l}\text { Keller, B } \\
\text { et al. }\end{array}$ & 2006 & Germany & $\begin{array}{l}\text { Journal } \\
\text { article }\end{array}$ & $\begin{array}{l}\text { Elderly people living at } \\
\text { home or in assisted living } \\
\text { settings }\end{array}$ & To report on music therapy services & $\begin{array}{l}\text { Multi-methods music } \\
\text { therapy }\end{array}$ & $\begin{array}{l}\text { Hints and experiences for music therapists } \\
\text { applying HBMT are given }\end{array}$ \\
\hline Mager, A & 2006 & Germany & $\begin{array}{l}\text { Journal } \\
\text { article }\end{array}$ & $\begin{array}{l}\text { HBMT for elderly, disabled } \\
\text { and isolated patients }\end{array}$ & Position paper & $\begin{array}{l}\text { No detailed } \\
\text { information }\end{array}$ & $\begin{array}{l}\text { Bringing music therapy to patients in } \\
\text { palliative care is considered to be a future } \\
\text { task }\end{array}$ \\
\hline Roberts, M & 2006 & Australia & $\begin{array}{l}\text { Journal } \\
\text { article }\end{array}$ & $\begin{array}{l}\text { Bereaved children and } \\
\text { adolescents }\end{array}$ & $\begin{array}{l}\text { To document and compare three types of } \\
\text { songwriting in HMBT }\end{array}$ & $\begin{array}{l}\text { Home-based } \\
\text { songwriting }\end{array}$ & $\begin{array}{l}\text { Different styles (improvised, computer } \\
\text { based, original) of songwriting for HBMT } \\
\text { are described and explored }\end{array}$ \\
\hline $\begin{array}{l}\text { Mirenkov N } \\
\text { et al. }\end{array}$ & 2009 & Japan & $\begin{array}{l}\text { Journal } \\
\text { article }\end{array}$ & $\begin{array}{l}\text { Elderly and disabled people } \\
\text { living at home }\end{array}$ & $\begin{array}{l}\text { To present and evaluate a concept for applying } \\
\text { mobile MT to human-computer interfaces, based } \\
\text { on Quality of Life Supporters (QLS) of self- } \\
\text { explanatory type, and oriented to elderly and } \\
\text { disabled people }\end{array}$ & $\begin{array}{l}\text { A selection of } \\
\text { precomposed classical } \\
\text { music with different } \\
\text { emotional characters }\end{array}$ & $\begin{array}{l}\text { Presentation of a concept for applying } \\
\text { mobile music therapy with human- } \\
\text { computer interfaces }\end{array}$ \\
\hline
\end{tabular}


like folk or pop songs. Brandes et al. [18] developed and refined two specific listening programs, one with newly composed polyphonic modern music and one with specifically arranged classical music in their four-armed study.

Often the personal preferences of the individual clients are taken into account when choosing the music. According to McBride [22], this is an important variable in producing a relaxation effect. For the music listening programs, the clients get basic technical equipment like cassette players, headphones, as well as tapes with preselected music.

Siedlecki [21] offered two music-listening programs in her study: one group listened to a standard music program (SM) and could choose from one of five relaxing instrumental music selections offered. For the second group, patterned music therapy programs (PM) with pleasant familiar instrumental or vocal music or the sounds of nature were offered to a) ease muscle tension or stiffness, b) facilitate sleep or to decrease anxiety, c) improve mood when someone feels sad, angry, or depressed, or d) improve energy level when someone feels fatigued.

The combination of music listening programs with additional therapeutic techniques, like guided imagery, gentle massages, or movement, was quite common $[19,27]$. Hanser \& Thompson [19] presented an eight-step music listening program on the basis of a cognitive-behavioural technique. This program was facilitated especially for use in the home environment and includes slow repetitive music to enhance falling asleep, rhythmic music to enhance energy, and also music listening in conjunction with drawing or painting. McBride [22] relates to this eight-step music listening protocol of Hanser \& Thompson in her work and gives her clients, who mainly suffer from chronic obstructive pulmonary disease, precise instructions on the use of music and how to use a music diary to document how their dyspnea and anxiety may have changed after listening to music.

In the field of active music therapy, singing and song writing are very common [24-26]. Pasiali [25] describes a three-step way from listening to singing for her work with autistic children: first she sings the song for the client accompanied by the guitar, then the client joins in and plays rhythmical instruments, like maracas or shaker eggs, to it and finally the client sings the song on his or her own. Chiang [24] offers a 'hello song' at the beginning and a 'good-bye song' at the end of a music therapy session. Activities in her sessions may also involve instrument playing, movement to music, listening, and singing.

In his study on music therapy with people with terminal cancer, Hilliard [23] describes that the techniques of music therapists were singing, lyric analysis, and music-prompted reminiscence as well as the planning of funerals or memorial services.
The information on duration of sessions shows a wide range: most authors reported that the average duration of a session can be between 20 to 60 minutes $[18,21,27,30]$. The frequency differs from one hour each day for seven days, to twice a day, and from a few times a week to as often as the client wants or needs to have a treatment of music therapy.

\section{Date of publication}

The dates of publication of the articles range from late 1980 to 2010. Four publications from the early years mainly concentrate on conditions and the development of special HBMT-programs, whereas from 2003 onward there is an increasing interest in HBMT as a model of ambulatory service and it is closely related to changes in healthcare systems.

\section{Fields of applications and patients}

Fields of applications of HBMT are similar in all studies: the majority of clients are the elderly living at home and people who need hospice and palliative care [19,21,23,27-29]. For these groups, HBMT is an accessible intervention because often the patients are no longer able to attend a hospital or a therapist's office. Another focus of HBMT is the work within the familysystem or with other caregivers or relatives [24-30]. This seems to be a specific and relevant aspect of HBMT, which provides the opportunity for the interaction and integration of family members and caregivers in the music therapy process.

In their study on the treatment of depression, Brandes et al. [18] argues that due to the fact that music therapy is generally not associated with negative side effects, it can be easily implemented with high treatment compliance.

Only the study from Pasiali [25] concentrates on HBMT for children. She investigated how prescriptive songs can promote the acquisition of social skills in autistic children.

\section{Legal aspects}

Naturally, legal aspects of HBMT are very closely linked to the peculiarities of the healthcare system of the specific country. For that reason the reports from out of practice give relevant information on how a music therapist can establish ambulatory work [31-33]. There is an interesting tendency concerning the main focuses of the publications; those from Germany mainly focus on legal aspects and conditions of a HBMT-setting in a changing healthcare system. Keller et al. [33] describe their motivation of establishing HBMT directly linked with the changes in healthcare politics and systems. They developed several ambulatory services initially for homes for the elderly and day care centres to address a new spectrum of clients and paying authorities. 


\section{Discussion}

For the first time, this review presents an overview of the field of home-based music therapy and describes settings and conditions represented by an international spectrum of articles.

According to our findings, publications on HBMT cover two main aspects. The first is the search for new fields and forms of work for music therapists alongside with the changes in the health care systems. The second aspect is to meet the challenges of a society with an increasing number of chronically ill patients and people of old age and low mobility and to adapt health care services accordingly.

The publications on HBMT show that receptive music therapy or singing songs with the clients play a predominant role in this working field. This might have organisational as well as economic reasons and takes into account the conditions of the ambulatory setting where the music therapist cannot carry too many instruments with him or her. Also the client as well as his or her relatives can listen to the music whenever it is wanted or needed. Accompaniment with a $C D$ can be helpful when singing familiar or preferred songs. Nevertheless, further development and investigation of music therapy techniques and programs for the specific use in a home-based setting are important for the future of HBMT. Such can be found in publications from Austria, Australia, and the United States.

The article by Horne-Thompson [34] might be helpful for finding out specific aspects of working in the home of a patient. She compares the role of music therapy within palliative care facility, as opposed to home, and looks at the differences of music therapy at a hospital and at a patient's home. Horne-Thompson states that although similar aims are addressed, the differences between hospital and home-based music therapy are striking. The author found that four factors influence the quality of a music therapy service in the home as opposed to the hospital: a) The way in which music therapy is introduced can ultimately determine whether or not a patient will participate, b) The role of the music therapist also varies enormously between a home and a hospital. Whereas in a hospital, music therapists are often perceived by patients as one of the less threatening health professionals, offering pleasant music and instruments, a visit at a patient's home may be experienced as invasive and intrusive due to the large number of health professionals involved in a patient's ambulatory care. c) The session length between home and hospital varies significantly; the direct contact time with a patient in his or her home is more than double the time spent with patients in the hospital. One possible explanation for this observation might be that patients and relatives often plan the daily schedule around the sessions which then results in fewer interruptions. d) One of the main differences is the presence of a spouse or family member while music therapy takes place. This means that they can give important and precise information about the patient's condition and can be involved in the session to address not only the needs of the patient, but also the needs of the family. Horne-Thompson [34] concludes that while family members are often present during sessions, the music therapist treats the family members alongside the patient.

This aspect of HBMT as a kind of "systemic music therapy approach" is the subject of several studies. Thomas et al. [28] found that music therapy in palliative care can assist family members in their role as caregivers while providing quality time with their loved ones.

While spousal caregivers of people with dementia experience the care for their spouse over long periods of time as a significant burden with ever increasing physical, emotional, and social strain, in their ongoing study Baker et al. [27] concentrate on the relationship of persons with dementia and their spousal caregivers. In this study, several specific hypotheses focusing on the caregiver's perceived quality of the spousal relationship as well as the caregiver's satisfaction with the care following the home-based music therapy intervention are tested. The authors assume that the promotion of the caregiver's well-being can keep committed couples living together in their own home and has, therefore, significant economizations. As the study is in progress, there are no results of this very interesting perspective of HBMT at the moment.

In her pilot project, Muthesius [29] investigated how music therapy can support caregivers and caring conditions in the home-based care setting of gerontopsychiatric patients. Muthesius was able to show that for people with dementia HBMT can not only relieve the strain on the care-recipients but also on the caregivers.

Chiang [24] presumes that music therapy in a home environment could help to enhance the child-parent bond. It is also more convenient for the family as HBMT is saving both caregiver and child from travelling to the sessions and it gives opportunities to other family members to be involved and get to know what music therapy is all about. Parents view music therapy as beneficial and enjoyable for their hospitalised child. Parents reported that music therapy could support them in understanding their child's ability to learn through music and how they could use music to interact with their child.

\section{Limitations of this review}

Although we are confident that our literature search with an extensive internet search, hand-searching of grey literature and relevant conference proceedings and 
communication with experts in the field has identified all relevant papers on HBMT, there might still be unexploited sources of studies we might have missed. However, according to Mc Auley [35], grey literature tends to include small trials with inconclusive results and thus this might not influence the conclusion of this review on the level of outcome. Nevertheless, on the level of implementation of services, valuable information might still be overseen this way. This limitation also holds for excluding publications from Asia. We are aware that the healthcare systems in countries like Japan or China are different than Western healthcare systems; however, it might be interesting to explore how outpatient services are realized under different conditions. In our review, only the paper of Mirenkov et al. [36] gives some insights into HBMT in Japan, mainly from the technical site. However, according to the fact sheet of music therapy in Japan from Ikuno [37], the typical population and the places music therapists work seem to be comparable. In particular, Ikuno points out that music therapy for developmentally disabled children is provided in the home of the client or therapist.

Finally, our internet search discovered a lot of HBMT initiatives in different countries which seem to be implemented in communal healthcare services. Unfortunately, a closer investigation did not reveal any publications about the outcomes of these services. As most of these services are integrated into local healthcare services for a longer time, successful outcomes can be assumed. In total, despite efforts to find all relevant publications, we can only give a fragmented view of the current state of play of HBMT without drawing a representative picture.

\section{Conclusion}

The main questions for this systematic overview were whether HBMT can be part of an innovative and effective service for people who have to be treated at home and, if this is possible, how could it be implemented. It was of particular interest to identify the types of clients and conditions that can be addressed by HBMT and to understand which specialized MT-approaches and settings are needed for a home-based service.

As a result of this review, there are only a few music therapy initiatives in the field of HBMT so far and quite a small number of clinical research publications in this area. Nevertheless, we were able to detect distinct fields of application for HBMT and special techniques for home-based services. The growing interest in HBMT in the last 10 years may indicate the potential of this service and refer to several advantages of HBMT as a future service in healthcare systems. HBMT is interesting for music therapists as well as for special groups of patients and their families and caregivers. This goes alongside the changing healthcare systems and its changing conditions but also it meets therapeutic challenges and needs of an ageing society with an increasing number of elderly and severely impaired people [38,39].

The possibility of integrating spouses, family members, or caregivers in HBMT and instructing them in selected music therapy techniques is an interesting aspect of future HBMT-services in view of lasting and economical aspects. It should be investigated in further studies. We would like to encourage researchers and music therapists to make distinct differentiations of approaches with clear research-based concepts for special groups of patients and to publish their results.

In a more global scope of public health, HBMT could serve as a blueprint for other researchers in the expanding field of home-based care services. Knowing more about the problems and challenges before implementing home-based care services may help to reduce the efforts in structural planning and to improve the quality of psychosocial support. This is not only limited to related interventions like art therapy, but also may hold true for other kinds of individualized mind-body therapies applied to an ever-growing amount of patients who are unable to leave their homes.

\section{Acknowledgements}

We would like to thank Katja Boehm and Katie Renaud for copyediting the paper. We also would like to thank all the authors of the papers mentioned in this review for their interest, cooperation, and support in screening the field of HMBT.

\section{Author details}

${ }^{1}$ The German Center for Neurodegenerative Diseases (DZNE), Witten, Germany. ${ }^{2}$ Center of Integrative Medicine \& Chair of Medical Theory, Integrative and Anthroposophical Medicine, Witten/Herdecke University, Herdecke, Germany.

\section{Authors' contributions}

WS and TO both developed the research design for the review. WS was responsible for the literature research and TO screened the grey literature and contacted the corresponding authors. WS was mainly responsible for the data extraction, while TO cross-checked the results. Both WS and TO carried out the qualitative analysis, discussed the results, and wrote the paper.

\section{Competing interests}

The authors declare that they have no competing interests.

Received: 12 April 2010 Accepted: 14 October 2010 Published: 14 October 2010

\section{References}

1. Bailey T: Music as Medicine: The History of Music Therapy since Antiquity. Notes 2001, 57(3):603-604.

2. Gold C, Heldal TO, Dahle T, Wigram T: Music Therapy for Schizophrenia or Schizophrenia-like Illnesses. Cochrane Database of Systematic Reviews 2006, 4.

3. Silverman MJ: The influence of music on the symptoms of psychosis: a meta-analysis. J Music Ther 2003, 40(1):27-40.

4. Ostermann T, Schmid W: Music Therapy in the Treatment of Multiple Sclerosis: a comprehensive literature review. Expert Rev Neurotherapeutics 2006, 6(4):469-77. 
5. Schmitt B, Frölich L: Creative Therapy Options for Patients with Dementia - A Systematic Review. Fortschr Neurol Psychiatr 2007, 75(12):699-707.

6. Anderson T: Music for Pain Relief. Pract Midwife 2006, 9(10):48-9.

7. Hoffmann P: Schöpferische Musiktherapie bei Menschen mit chronischen Schmerzen. Musiktherapeutische Umschau 1997, 18:3-14.

8. Pierce CM, Schwartz D, Thomas EM: Music Therapy in a day care centre. Dis Nerv Syst 1964, 25:29-32.

9. Kusatz M, Ostermann T, Aldridge D: Auditive Stimulation Therapy as an Intervention in Subacute and Chronic Tinnitus: a Prospective Observational Study. Int Tinnitus J 2005, 11(2):163-9.

10. Mandel SE, Hanser SB, Secic M, Davis BA: Effects of Music Therapy on Health-Related Outcomes in Cardiac Rehabilitation: a Randomized Controlled Trial. J Music Ther 2007, 44(3):176-97.

11. Emery CF, Hsiao ET, Hill SM, Frid DJ: Short-Term Effects of Exercise and Music on Cognitive Performance among Participants in a Cardiac Rehabilitation Program. Heart Lung 2003, 32(6):368-73.

12. Waldon EG: The Effects of Group Music Therapy on Mood States and Cohesiveness in Adult Oncology Patients. J Music Ther 2001, 38(3):212-38.

13. Pavlicevic M, Ansdell G: Community Music Therapy London, Philadelphia: Jessica Kingsley Publishers 2004.

14. Tüpker R: Neue Wege der Musiktherapie. Musiktherapeutische Umschau 2006, 27(3):216-226.

15. Schmid W: "Swing in my Brain": Active Music Therapy for People with Multiple Sclerosis. In Music Therapy in Neurological Health Care Settings. Performing Health. Edited by: Aldridge D. London, Philadelphia: Jessica Kingsley Publishers; 2005:161-188.

16. Liberati A, et al: The PRISMA statement for reporting systematic reviews and meta-analyses of studies that evaluate health care interventions: explanation and elaboration. PLoS Med 2009, 6(7):e1000100, Epub 2009 Jul 21.

17. Jadad AR, Haynes RB, Hunt D, Browman GP: The internet and evidencebased decision-making: a needed synergy for efficient knowledge management in health care. Canadian Medical Association Journal 2000, 162(3):362-365.

18. Brandes V, et al: Receptive Music Therapy for the Treatment of Depression: A Controlled Clinical Trial of Efficacy. Psychotherapy and Psychosomatics 2010, 79:321-322.

19. Hanser SB, Thompson LW: Effects of Music Therapy Strategy on Depressed Older Adults. J Gerontol 1994, 49:265-269.

20. Shiraishi IM: A home-based music therapy program for multi-risk mothers. Music Therapy Perspectives 1997, 15:16-23.

21. Siedlecki SL: The Effect of Music on Power, Pain, Depression, and Disability: a Clinical Trial. Dissertation for the degree of Doctor of Philosophy Frances Payne Bolton School of Nursing Case Western Reserve University 2005.

22. McBride S, Graydon J, Sidani S, Hall L: The Therapeutic Use of Music for Dyspnea and Anxiety in Patients with COPD who live at Home. J Holist Nurs 1999, 17(3):229-50.

23. Hilliard RE: The Effects of Music Therapy on the Quality and Lenght of Life of People diagnosed with Terminal Cancer. Journal of Music therapy 2003, 40:113-37.

24. Chiang JYK: Music Therapy for Young Children who have special needs: The Music Therapy Experience from the perspectives of carers and professionals. Master Thesis The New Zealand School of Music, Wellington, New Zealand 2008.

25. Pasiali V: The Use of Prescriptive Therapeutic Songs in a Home-Based Environment to Promote Social Skills Acquisition by Children with Autism: Three Case Studies. Music Therapy Perspectives 2004, 22(1):11-20.

26. Roberts M: "I Want to Play and Sing My Story": Home-Based Songwriting for Bereaved Children and Adolescents. The Australian Journal of Music Therapy 2006, 17:18-34.

27. Research Project Spotlight: Home-based Music Intervention Study. Ageing Mind Initiative Newsletter 08/2009 3[http://www.uq.edu.au/ami/ docs/Aug_09_Newsletter.pdf].

28. Thomas A: Does Music Therapy Work? Evaluating the Effectiveness of Music Therapy in Community Based Palliative Care. Palliative Care Australia Conference Perth, Australia, September 2009.

29. Muthesius D, et al: Balsam für die Seele: Hausmusik. Abschlußbericht des Modellprojekts: Verbesserung der häuslichen Pflegesituation gerontopsychiatrischer Patienten unter Einsatz von Musiktherapie. Kuratorium Deutsche Altershiffe Köln 2005.
30. Chapman A: Home based music therapy. 30th NATIONAL CONFERENCE OF THE AUSTRALIAN MUSIC THERAPY ASSOCIATION The Victorian Arts Centre 2004.

31. Weber S: In der Musiktherapie zu Hause - Neue Wege der ambulanten Therapie. Master thesis University of Applied Science Heidelberg, Department of Music Therapy 2003

32. Oliver S: Music Therapy Services of Arizona: an Alternative Approach to Service Provision. Journal of Music Therapy 1989, XXVI(2):95-99.

33. Keller B, Klären C, Pfefferle U: Musik auf Rädern GbR - ambulante Musiktherapie. In Jahrbuch Musiktherapie Band 2. Edited by: Schirmer H. Wiesbaden: Reichert Verlag; 2006:, (Hg).

34. Horne-Thompson A: Expanding from Hospital to Home Based Care: Implications for Music Therapists Working in Palliative Care. Australian Journal of Music Therapy 2003, 14:38-49.

35. McAuley L, Pham B, Tugwell P, Moher D: Does the inclusion of grey literature influence estimates of intervention effectiveness reported in meta-analyses? Lancet 2000, 356:1228-31.

36. Mirenkov N, Kanev K, Takezawa H: Mobile Music Therapy with Multimedia Quality of Life Supporters for Elderly and Disabled. Journal of Multimedia 2009, 5(1):29-44.

37. Ikuno R: Fact Sheet of Music Therapy in Japan. Voices: A World Forum for Music Therapy 2005, 5(1):mi40005000167[http://www.voices.no/mainissues/ mi40005000167.html].

38. Mager A: Musiktherapie zuhause. Musiktherapeutische Umschau 2006 , 27(3):261-64.

39. Hanser SB: A Music Therapy Strategy for Depressed Older Adults in the Community. The Journal of Applied Gerontology 1990, 9(3):283-298.

\section{Pre-publication history}

The pre-publication history for this paper can be accessed here: http://www.biomedcentral.com/1472-6963/10/291/prepub

doi:10.1186/1472-6963-10-291

Cite this article as: Schmid and Ostermann: Home-based music therapy - a systematic overview of settings and conditions for an innovative service in healthcare. BMC Health Services Research 2010 10:291.

\section{Submit your next manuscript to BioMed Central and take full advantage of:}

- Convenient online submission

- Thorough peer review

- No space constraints or color figure charges

- Immediate publication on acceptance

- Inclusion in PubMed, CAS, Scopus and Google Scholar

- Research which is freely available for redistribution 